\title{
Instrumen Penilaian Motivasi Belajar dan Hasil Belajar IPA Siswa Kelas V Sekolah Dasar
}

\author{
Kadek Arya Mudanta' ${ }^{1}$ I Gede Astawan², I Nyoman Laba Jayanta ${ }^{3}$ \\ ${ }^{123}$ Prodi Pendidikan Guru Sekolah Dasar, FIP \\ Universitas Pendidikan Ganesha \\ Singaraja, Indonesia \\ e-mail: aryamudanta98@gmail.com¹, igedeastawan@undiksha.ac.id², laba.jayanta@undiksha.ac.id ${ }^{3}$
}

\begin{abstract}
Abstrak
Penelitan ini bertujuan untuk mengembangkan instrumen penilaian motivasi belajar dan hasil belajar IPA. Model pengembangan yang digunakan pada penelitian ini yaitu 4D, terdiri dari define, design, develop, dan disseminate. Penelitian pengembangan ini hanya dilakukan sampai tahap develop. Subyek penelitian ini adalah instrumen penilaian motivasi belajar dan hasil belajar IPA berupa kisi-kisi, lembar kuisioner dan tes hasil belajar IPA. Data yang dikumpulkan menggunakan metode angket dan tes. Data yang diperoleh akan dianalisis validitas dan reliabilitas masing-masing instrumen. Nilai rata-srata sebesar 0,92 dan 1 didapatkan dari hasil analisis validitas intrumen penilaian motivasi belajar dan hasil belajar, artinya kedua instrumen penilaian ini memilki validitas yang sangat tinggi. Sedangkan hasil analisis reliabilitas intrumen penilaian motivasi belajar adalah 0,86 dan hasil belajar IPA 0,87, artinya kedua instrumen ini memiliki tingkat reliabilitas yang tinggi. Dari hasil yang diperoleh, maka dapat dinyatakan bahwa pengembangan instrumen penilaian motivasi belajar dan hasil belajar IPA layak dikembangkan dan digunakan untuk melakukan penilaian kepada siswa.
\end{abstract}

Kata kunci: instrumen, motivasi, hasil, belajar, IPA.

\begin{abstract}
This research aim to evolve an instrument of learning motivation assessment and natural science learning outcome. The development model used in this research was $4 D$, consists of define, design, develop, and disseminate. This study was only carried out until the develop stage. The subject of this research was science learning evaluation instrument consisting of a grid, questionnaire sheet and a test of natural science learning outcome. Data collected using questionnaire and test methods. The data would be analyzed for the validity and reliability of each instrument. The average value 0.92 and 1 obtained from the results of the learning motivation assessment and learning outcome instrument validity analysis, which means that both of these assessment instruments have a very high validity. While the results of the learning motivation assessment instruments reliability analysis 0.86 and natural science learning outcome 0.87 , which means that both of these instruments have a high level of reliability. From these results, it could be explained that the development of learning motivation assessment and natural science learning outcome instrument were feasible to be developed and used to make assessment of student.
\end{abstract}

Keywords: instruments, motivation, result, study, natural science.

\section{Pendahuluan}

Pada hakikatnya tujuan hidup manusia adalah untuk tetap hidup dan menjadikan kehidupan yang lebih baik dan layak. Untuk mendapatkan hal tersebut, seseorang harus memiliki hal yang kompleks dalam kehidupannya berupa sebuah wawasan, perilaku dan

\footnotetext{
${ }^{*}$ Corresponding author.

Received 20 April 2020, Accepted 20 Juni 2020; Available online 5 Juli 2020 (C) 2020 MI All Rights Reserved
} 
keahlian yang baik. Ketiga komponen itu dapat diperoleh melalui pendidikan. Sujana (2019), pendidikan adalah cara yang dilakukan untuk membantu jiwa peserta didik secara lahir dan batin untuk menjadi manusia yang lebih baik. Menurut Dewantara (dalam Marwah, dkk, 2018), pendidikan merupakan berbagai upaya yang dilakukan orang tua kepada anak untuk menyokong kemajuan hidupnya. Jadi, pendidikan adalah suatu upaya untuk menciptakan manusia yang lebih baik.

Pendidikan di Negara Indonesia salah satunya dapat diperoleh melalui lembaga pendidikan formal. Satuan pendidikan terpenting dalam menampung prosedur pendidikan formal adalah Sekolah Dasar (SD). Banyak pembelajaran yang diajarkan di sekolah dasar, satu diantaranya yaitu IImu Pengetahuan Alam (IPA). Astalini \& Kurniawan (2019) menjelaskan bahwa IPA merupakan proses yang dilalui peserta didik yang menghasilkan pemahaman berupa konsep-konsep yang berkaitan tentang alam. Agustini, dkk (2016) menyatakan bahwa pada jenjang pendidikan dasar pembejaran IPA bertujuan menyiapkan siswa melalui beragam kompetensi serta keahlian beradaptasi di dalam berbagai lingkungan dan tantangan yang akan ditemukan di masa depan. Sedangkan menurut De Vito (dalam Norazaini, 2017) berpendapat bahwa pembelajaran IPA yang efektif adalah IPA yang menghubungkan dengan kegiatan sehari-hari, peserta didik diberikan peluang dalam mengasah skill yang dimiliki, serta membangun pemahaman kepada siswa bahwa pelajaran IPA itu penting dalam kehidupan ini.

Pembelajaran IPA dapat diterima dengan baik, apabila siswa memiliki ketertarikan atau dorongan yang tinggi dalam melakukan learning process serta didampingi oleh guru yang baik dalam mengelola proses pembelajaran. Sedangkan, jika peserta didik tidak mempunyai ketertarikan atau dorongan yang baik dan tidak diimbangi dengan guru yang baik dalam mengelola proses pembelajaran, maka pembelajaran IPA tidak mampu dipahami oleh peserta didik. Jika pembelajaran IPA tidak mampu dipahami oleh peserta didik, maka sangat berdampak pada hasil belajar siswa terhadap pembelajaran IPA.

Hasil observasi dan wawancara pada tanggal 21 dan 22 Oktober tahun 2019 di SDN 1 Sepang Kelod Kecamatan Busungbiu khususnya di kelas $\mathrm{V}$ pada mata pelajaran IPA menunjukkan motivasi belajar siswa yang kurang dan hasil belajar yang masih di bawah Kriteria Ketuntasan Minimal (KKM). Untuk melengkapi hasil wawancara dan observasi yang telah dilakukan, maka dilanjutkan dengan studi dokumen nilai UTS IPA siswa kelas V SDN 1 Sepang Kelod Kecamatan Busungbiu tahun pelajaran 2019/2020. Berdasarkan dari hasil studi dokumen nilai ulangan tengah semester IPA menunujukkan masih banyak siswa yang mendapatkan nilai di bawah Kriteria Ketuntasan Minimal (KKM). Ini membuktikan bahwa masih rendahnya motivasi belajar dan hasil belajar IPA siswa kelas V SDN 1 Sepang Kelod Kecamatan Busungbiu Tahun Pelajaran 2019/2020.

Adapun beberapa penyebab rendahnya motivasi belajar dan hasil belajar IPA berdasarkan observasi di kelas V SDN 1 Sepang Kelod Kecamatan Busungbiu, di antaranya guru masih belum mampu memaksimalkan penerapan suatu model pembelajaran inovatif, kurangnya proses tanya jawab selama pembelajaran, dan guru sering mengalami kesulitan untuk menilai tingkat motivasi belajar dan hasil belajar yang telah dicapai siswa karena alat evaluasi yang digunakan tidak dapat mengukur dengan baik dan tidak sesuai dengan yang harus diukur, sehingga data yang didapatkan tidak akurat dan salah.

Berdasarkan hasil kajian literatur dan argumentasi logis penulis maka solusi yang dapat diberikan yaitu dengan mengembangkan suatu instrumen yang dapat digunakan guru untuk menilai motivasi belajar dan hasil belajar siswanya. Solusi ini dipilih mengingat jika instrumen tersebut terus digunakan, maka akan memberikan penilaian yang bias. Penelitian pengembangan ini memiliki perbedaan dengan penelitian pengembangan sebelumnya yang dilakukan oleh Trimawati, dkk (2020); Astalini \& Kurniawan (2019); dan Hamid (2016). Perbedaannya terletak pada subjek penelitian yang digunakan yaitu sekolah dasar serta varibel yang digunakan yaitu motivasi belajar dan hasil belajar siswa. Dalam menentukan instrumen penilaian motivasi belajar dan hasil belajar siswa, guru harus dapat menentukan instrumen penilaian yang tepat yang dapat menilai sejauh mana tingkat motivasi dan hasil belajar siswa dalam proses pembelajaran. Instrumen motivasi belajar yang dikembangkan 
pada penelitian ini adalah instrumen motivasi belajar dalam bentuk kuisioner (angket) dan instrumen penilaian hasil belajar yang dikembangkan adalah bentuk tes pilihan ganda (obyektif).

Motivasi merupakan sesuatu yang penting bagi seseorang. Menurut Uno (dalam Arjuniwati, 2019), motivasi berakar dari kata -motifill yang bermakna sebagai suatu tekad yang ada dalam diri individu untuk melakukan suatu kegiatan. Monika \& Adman (dalam Andriani \& Rasto, 2019) mendefinisikan motivasi sebagai daya dorong untuk menumbuhkan dan meningkatkan semangat dalam aktivitas belajar. Motivasi yang ada dalam diri siswa sangat berpengaruh terhadap perkembangan dalam berproses dan hasil belajar siswa.

Hasil belajar dapat didefinisikan sebagai suatu hal yang penting dalam proses pembelajaran, karena hasil belajar yang didapat siswa mencerminkan pemahaman siswa. Kennedy (dalam Maulida \& Mukminan, 2016) hasil belajar merupakan hasil yang menjelaskan tentang pemahaman atau kemampuan peserta didik dalam learning process. Menurut Yusuf (2015) hasil belajar merupakan suatu simbol keberhasilan atau capaian siswa dalam proses pembelajaran. Sedangkan Sudjana (dalam Huntaruk \& Simbolon, 2018), hasil belajar adalah kompetensi yang peserta didik miliki sesudah menjalani pengalaman belajar. Jadi, hasil belajar yaitu suatu kemampuan yang dimiliki peserta didik sesudah melaksanakan proses belajar pada waktu tertentu, hasil belajar juga dijadikan sebagai ukuran untuk menilai pemahaman peserta didik dalam learning process.

Merujuk pada penjelasan di atas, maka dilakukan penelitian yang berjudul "Instrumen Penilaian Motivasi Belajar dan Hasil Belajar IPA Siswa Kelas V Sekolah Dasar". Penelitian ini bertujuan untuk mengembangkan instrumen yang layak dalam melakukan penilaian motivasi belajar dan hasil belajar IPA.

\section{Metode}

Jenis dari penelitian ini adalah Research and Development. Model pengembangan yang digunakan pada penelitian ini yaitu 4D, terdiri dari define, design, develop, dan disseminate (Thiagarajan dalam Dewi \& Akhlis, 2016). Namun, tahapan disseminate tidak dapat dilaksanakan mengingat keterbatas waktu dan finansial.

Pada penelitian ini pelaksanaan model 4D terdiri dari: (1) Fase define merupakan fase awal atau menjadi pondasi awal dalam melakukan sebuah penelitian. (2) Fase pendefinisian ini terdiri atas analisis kebutuhan, analisis karakteristik siswa, analisis tugas. Tahap design merupakan tahap yang di dalamnya berisikan sebuah rencana. Adanya tahap perancangan bertujuan untuk membuat rencana atau kerangka awal instrumen penilaian motivasi belajar dan hasil belajar IPA. (3) Fase develop merupakan fase yang digunakan dalam mengahasilkan suatu produk pengembangan. Fase develop ini memilki tujuan dalam menghasilkan instrumen penilaian sesudah melewati proses bimbingan dan perbaikan. Tahap ini terdiri dari penilaian ahli yang dilakukan dengan cara pengujian analisis validasi isi menggunakan lembar validasi yang diserahkan kepada ahli, kemudian ahli akan memberikan penilaian dan masukan yang berguna untuk perbaikan dan penyempurnaan produk yang dihasilkan dan uji pengembangan produk (developmental testing) yang mengujicobakan instrumen ke 3 SD yang berbeda, yaitu SD Negeri 3 Banjar Jawa sebanyak 32 siswa, SDN 5 Banyuasri sebanyak 34 siswa, dan SDN 1 Astina sebanyak 24 siswa.

Instrumen motivasi belajar siswa yang digunakan berupa kisi-kisi dan lembar kuesioner. Sugiyono (2017), kuesioner adalah teknik pengambilan data yang terdiri dari kumpulan pertanyaan yang diserahkan kepada responden. Widoyoko (dalam Purnomo \& Palupi, 2016) kuesioner yaitu metode pengambilan data berupa pertanyaan tertulis ke responden. Sedangkan instrumen hasil belajar IPA siswa digunakan berupa kisi-kisi dan lembar tes objektif. Arikunto (dalam Aji \& Winarno, 2016) tes yaitu kumpulan masalah dalam bentu pertanyaan yang diserahkan kepada peserta didik untuk mengukur pemahaman dan keahlian peserta didik. Azwar (dalam Suharman, 2018), tes merupakan prosedur yang sistematik yang disusun sesuai dengan teknik dan aturan tertentu. 
Instrumen penilaian motivasi belajar disusun berdasarkan indikator menurut Uno (2008) yaitu: (1) adanya hasrat dan keinginan berhasil; (2) adanya dorongan dan kebutuhan dalam belajar; (3) adanya harapan dan cita-cita masa depan; (4) adanya penghargaan dalam belajar; (5) adanya kegiatan yang menarik dalam belajar; (6) adanya lingkungan belajar yang kondusif, sehingga memungkinkan seseorang siswa dapat belajar dengan baik. Indikator tersebut dikembangkan menjadi 24 pernyataan yang terbagi atas 12 pernyataan positif dan 12 pernyataan negatif. Instrumen hasil belajar IPA disusun berdasarkan KD dari tema 8 yang dikembangkan menjadi 10 indikator dan menghasilkan 30 butir soal obyektif. Setiap butir soal terdapat 4 alternatif jawaban yang akan dipilih oleh siswa. Instrumen yang dihasilkan berupa kisi-kisi dan lembar tes obyektif yang berjumlah 30 butir soal.

Penelitian ini menggunakan teknik analisis data berupa analisis validitas dan analisis reliabilitas instrumen. Pada analisis validitas terbagi atas analisis validitas isi dan validitas butir. Validitas isi instrumen motivasi belajar dan hasil belajar IPA diuji dua orang ahli dan skor hasilnya dimasukkan dalam tabel tabulasi silang disajikan pada Tabel 1.

Tabel 1 Tabulasi Silang

\begin{tabular}{cccc}
\hline & & \multicolumn{2}{c}{ Ahli 2 } \\
\cline { 3 - 4 } & & Kurang relevan & Sangat relevan \\
\hline \multirow{2}{*}{ Ahli 1} & Kurang relevan & A & B \\
\cline { 2 - 4 } & Sangat relevan & C & D \\
\hline
\end{tabular}

Hasil validasi kedua ahli yang sudah dimasukkan ke dalam tabel tabulasi silang dianalisis menggunakan rumus Gregory sebagai berikut.

$$
V=\frac{D}{A+B+C+D}
$$

\section{Keterangan:}

$\mathrm{Vi} \quad=$ Validitas Isi

A $\quad=$ Kedua ahli tidak setuju

$\mathrm{B} \quad=$ Ahli 1 tidak setuju, ahli 2 setuju

C = Ahli 1 setuju, ahli 2 tidak setuju

$\mathrm{D} \quad=$ Kedua ahli setuju

Hasil perhitungan yang didapat, dicocokan terhadap kriteria koefisien validitas isi. Adapun rincian kriteria validitas isi dapat diuraikan dalam Tabel 2.

Tabel 2 Kriteria Validitas isi

\begin{tabular}{cc}
\hline Koefisien Validitas Isi & Kriteria \\
\hline $0,00-0,19$ & Sangat rendah \\
\hline $0,20-0,39$ & Rendah \\
\hline $0,40-0,59$ & Sedang \\
\hline $0,60-0,79$ & Tinggi \\
\hline $0,80-1,00$ & Sangat tinggi \\
\hline
\end{tabular}

Validitas butir diperuntukkan dalam memahami jumlah butir instrumen yang valid dan gugur. Validitas butir instrumen kuisioner motivasi belajar dicari dengan kolerasi product moment. Berikut ini disajikan rumus kolerasi product moment (Koyan, 2011).

$$
\mathrm{r}_{\mathrm{xy}}=\frac{N \sum X Y-\left(\sum X\right)\left(\sum Y\right)}{\sqrt{\left(N \sum X^{2}-\left(\sum X\right)^{2}\right.}\left(N \sum Y^{2}-\left(\sum Y\right)^{2}\right)}
$$




\section{Keterangan:}

$r_{x y} \quad=$ Kolerasi antara skor butir dengan skor total

$\mathrm{X}=$ Skor responden untuk butir yang dicari validitasnya

$\mathrm{Y}=$ Skor total responden

$\mathrm{N} \quad=$ Banyak responden atau peserta tes $5 \%$.

Kriteria butir instrumen dikatakan valid bilamana $r_{\text {xyhitung }}>r_{x y t a b e l}$ dengan taraf signifikasi

Validitas butir tes hasil belajar dihitung dengan kolerasi point biserial. Berikut ini disajikan rumus kolerasi point biserial (Candiasa, 2011).

$y_{\mathrm{pbi}}=\frac{M p-M t}{S t} \sqrt{\frac{p}{q}}$

Keterangan:

$y_{p b i}=$ Teknik korelasi point biserial

$M_{p} \quad$ = Rerata skor subjek yang menjawab benar

$M_{t} \quad=$ Rerata skor total

$S_{t} \quad=$ Standar deviasi skor total

$p \quad=$ Proporsi peserta didik yang dijawab benar

$q \quad=$ Proporsi peserta didik yang menjawab salah $(q=1-p)$

Setelah uji validitas selesai, maka dilakukan uji reliabilitas. Hal ini dikarenakan uji reliabilitas hanya dikhususkan pada butir instrumen yang valid. Pada instrumen motivasi belajar menurut Koyan (2011), untuk menguji reliabilitas instrumen yang bersifat politomi maka digunakan rumus Alpha-Cronbach.

$$
\mathrm{r}_{11}=\left(\frac{n}{n-1}\right)\left(\frac{S_{t}^{2} \sum p q}{S_{t}^{2}}\right)
$$

\section{Keterangan:}

$r_{1.1}=$ Koefisien reliabilitas perangkat tes

$\mathrm{n} \quad=$ Banyak butir tes

$\mathrm{S}_{\mathrm{t}} \quad=$ Standar deviasi skor total

$\mathrm{p} \quad=$ Proporsi siswa yang menjawab benar untuk tiap-tiap butir

$\mathrm{q}=$ = Proporsi siswa yang menjawab salah untuk tiap-tiap butir

Hasil perhitungan yang diperoleh, dibandingkan dengan kriteria derajat reliabilitas. Menurut Candiasa (2011), kriteria untuk menentukan derajat reliabilitas diuraikan dalam Tabel 3.

Tabel 3 Kriteria Reliabilitas Instrumen

\begin{tabular}{cc}
\hline Koefisien Reliabilitas & Kriteria \\
\hline $0,80<\mathrm{r}_{11} \leq 1,00$ & Sangat tinggi \\
\hline $0,60<\mathrm{r}_{11} \leq 0,80$ & Tinggi \\
\hline $0,40<\mathrm{r}_{11} \leq 0,60$ & Sedang \\
\hline $0,20<\mathrm{r}_{11} \leq 0,40$ & Rendah \\
\hline $\mathrm{r}_{11} \leq 0,20$ & Sangat rendah \\
\hline
\end{tabular}

Menurut Agung (2011) untuk menghitung reliabilitas tes hasil belajar digunakan rumus Kuder Richardson 20 (KR 20). 


$$
K-R 20=\left(\frac{k}{k-1}\right)\left(\frac{S_{t}^{2} \sum p q}{S_{t}^{2}}\right)
$$

Keterangan:

$\mathrm{k} \quad=$ Jumlah item dalam instrumen

$\mathrm{S}_{\mathrm{t}}^{2} \quad=$ Varians total

$\mathrm{p} \quad=$ Proporsi subyek yang menjawab benar

$\mathrm{q} \quad=$ Proporsi subyek yang menjawab salah $(\mathrm{q}=1-\mathrm{p})$

Dalam menentukan butir-butir item yang handal atau tidaknya, maka harus dibandingkan nilai $r$ hitung dengan $t$ tabel (taraf signifikansi 5\%). Butir item dikatakan handal bilamana nilai $r$ hitung $>\mathrm{t}$ tabel. Tetapi bilamana nilai $r$ hitung $<\mathrm{t}$ tabel, butir item dikatakan tidak handal. Kriteria tingkat reliabilitas diuraikan pada Tabel 4.

Tabel 4 Kriteria Reliabilitas Instrumen

\begin{tabular}{cc}
\hline Skor & Kriteria \\
\hline $0,80-1,00$ & Sangat tinggi \\
\hline $0,60-0,80$ & Tinggi \\
\hline $0,40-0,60$ & Sedang \\
\hline $0,20-0,40$ & Rendah \\
\hline $0,0-0,20$ & Sangat rendah \\
\hline
\end{tabular}

\section{Hasil dan Pembahasan}

Hasil pengembangan ini berupa instrumen motivasi belajar dan hasil belajar IPA kelas $\mathrm{V}$ pada tema 8. Model pengembangan yang digunakan pada penelitian ini yaitu 4D, terdiri dari define, design, develop, dan disseminate. Penelitian pengembangan ini hanya dilakukan sampai tahap develop. Instrumen yang digunakan untuk menilai motivasi belajar siswa adalah kuesioner, sedangkan instrumen yang digunakan untuk menilai hasil belajar IPA adalah berupa obyektif test. Instrumen penilaian motivasi belajar disusun berdasarkan indikator menurut Uno (2008) yaitu: (1) adanya hasrat dan keinginan berhasil; (2) adanya dorongan dan kebutuhan dalam belajar; (3) adanya harapan dan cita-cita masa depan; (4) adanya penghargaan dalam belajar; (5) adanya kegiatan yang menarik dalam belajar; (6) adanya lingkungan belajar yang kondusif, sehingga memungkinkan seseorang siswa dapat belajar dengan baik. Instrumen hasil belajar IPA disusun berdasarkan KD dari tema 8 yang dikembangkan menjadi 10 indikator.

Pengembangan instrumen penilaian motivasi belajar berupa kisi-kisi dan lembar kuisioner (angket) yang berjumlah 24 pernyataan dilakukan uji validitas isi dengan dua orang ahli sebagai penilai. Hasil analisis data menunjukkan bahwa sebanyak 22 butir yang relevan dan 2 butir pernyataan yang tidak relevan. Tahap selanjutnya uji validitas dan reliabilitas dapat diuraikan pada Tabel 5.

Tabel 5 Hasil Analisis Validitas Isi dan Reliabilitas Instrumen Motivasi Belajar Siswa

\begin{tabular}{lcc}
\hline \multicolumn{1}{c}{ Analisis/Uji } & Hasil & Kriteria \\
\hline Validitas isi & 0,92 & Sangat Tinggi \\
\hline Reliabilitas & 0,86 & Sangat Tinggi \\
\hline
\end{tabular}

Berdasarkan Tabel 5 di atas, hasil analisis validitas isi instrumen motivasi belajar siswa pada mata pelajaran IPA dengan rumus Gregory diperoleh sebesar 0,92 dan berada pada kriteria validitas sangat tinggi. Selanjutnya, hasil analisis uji reliabilitas instrumen dengan rumus Alpha-Cronbach didapat sebesar 0,86 dan berada pada kriteria reliabilitas sangat tinggi. 
Instrumen hasil belajar IPA disusun berdasarkan KD dari tema 8 yang dikembangkan menjadi 10 indikator dan menghasilkan 30 butir soal obyektif. Setiap butir soal terdapat 4 alternatif jawaban yang akan dipilih oleh siswa. Instrumen yang dihasilkan berupa kisi-kisi dan lembar tes obyektif yang berjumlah 30 butir soal dilakukan uji validitas isi dengan dua orang ahli sebagai penilai. Hasil analisis data menunjukkan bahwa sebanyak 30 butir yang relevan. Tahap selanjutnya uji validitas dan reliabilitas dapat diuraikan pada Tabel 6.

Tabel 6 Hasil Analisis Validitas Isi dan Reliabilitas Instrumen Hasil Belajar IPA Siswa

\begin{tabular}{lcl}
\hline \multicolumn{1}{c}{ Analisis/Uji } & Hasil & Kriteria \\
\hline Validitas isi & 1,00 & Sangat Tinggi \\
\hline Reliabilitas & 0,87 & Sangat Tinggi \\
\hline
\end{tabular}

Merujuk pada tabel 6 di atas, hasil analisis validitas isi instrumen hasil belajar IPA siswa dengan menggunakan rumus Gregory diperoleh sebesar 1,00 serta termasuk ke dalam kriteria validitas sangat tinggi. Selanjutnya, hasil analisis uji reliabilitas instrumen dengan rumus KR 20 didapat sebesar 0,87 dan berada pada kriteria reliabilitas sangat tinggi.

Berdasarkan hasil di atas, dikatakan bahwa instrumen motivasi belajar dan hasil belajar IPA mempunyai nilai validitas dan reliabilitas yang tinggi. Hayati \& Lailatussaadah (2016), data dikatakan semakin akurat bilamana nilai validitas dan reliabilitas instrumennya juga semakin tinggi.

Hasil penelitian ini didukung oleh penelitian Muttaqin \& Kusaeri (2017) yang menunjukkan instrumen yang dikembangkan sangat valid dengan rata-rata total validitas sebesar 3,6 dan memilik reliabilitas yang sangat tinggi sebesar 0,819 . Peneliti lain yang mendukung adalah penelitian Dewi \& Prasetyo (2016) yang menunjukkan instrument penilaian IPA yang terdiri dari 36 item memiliki validitas yang sangat tinggi sebesar 1,00 dan reliabilitas yang sangat tinggi sebesar 0,90 , sehingga dapat disimpulkan instrumen sangat layak digunakan.

Instrumen penilaian motivasi belajar dan hasil belajar layak untuk dikembangkan karena instrumen penilaian merupakan suatu yang harus ada dalam proses pembelajaran sebagai alat bantu yang digunakan untuk memperoleh segala informasi untuk mengetahui tingkatan kemampuan siswa secara objektif. Sejalan dengan Arikunto (dalam Hardiani, 2017) instrumen merupakan suatu alat yang digunakan untuk memudahkan proses pengumpulan data tertentu secara efektif. Gronlund (dalam Abdullah, 2015), penilaian merupakan suatu yang dilakukan secara bertahap yang terdiri dari tahap mengumpulkan, menganalisis, dan menerjemahkan informasi untuk mengetahui tingkat pemahaman atau keterampilan yang dicapai oleh siswa. Instrumen dikatakan baik menurut Winarno (dalam Aji \& Winarno, 2016) apabila memiliki krtiteria diantaranya memiliki validitas, reliabilitas, memiliki nilai kepraktisan.

\section{Simpulan}

Merujuk pada hasil dan pembahasan, dapat ditarik kesimpulan diantaranya: (1) pengembangan instrumen penilaian motivasi belajar berupa kuesioner yang berjumlah 24 pernyataan yang terbagi atas 12 pernyataan positif dan 12 pernyataan negatif. Hasil analisis data menunjukkan bahwa sebanyak 22 butir yang relevan dengan validitas sebesar 0,92 dan memiliki reliabilitas sebesar 0,86 yang berarti validitas dan reliabilitas instrument motivasi belajar berada pada kriteria sangat tinggi. Sehingga instrumen ini sudah tepat dan layak digunakan untuk menilai motivasi belajar siswa. (2) pengembangan instrumen penilaian hasil belajar IPA memakai obyektif test yang berjumlah 30 soal. Hasil analisis data menunjukkan bahwa semua butir soal relevan, dengan validitas 1,00 dan memiliki reliabilitas 0,87 yang berarti validitas dan reliabilitas instrumen hasil belajar IPA masuk dalam kriteria sangat tinggi. Sehingga instrumen ini sudah tepat dan layak digunakan untuk mengukur hasil belajar IPA siswa. Adapun saran yang dapat disampaikan diantaranya: (1) Pendidik hendaknya menyampaikan materi dengan penuh motivasi yang membuat hasil belajar siswa berkembang 
dan melakukan penilaian terhadap motivasi belajar dan hasil belajar siswa dengan menggunakan instrumen yang telah memenuhi syarat alat ukur yang baik. (2) Kepala Sekolah hendaknya memfasilitasi guru untuk meningkatkan keterampilannya dalam mengembangkan instrumen atau alat evaluasi pembelajaran yang berkualitas sehingga mampu melaksanakan penilaian dengan baik. (3) Peneliti lain hendaknya menggunakan hasil penelitian ini sebagai acuan dalam mengembangkan instrumen penilaian dengan topik atau mata pelajaran lain, tetapi untuk tetap mengeksplorasi sumber yang lebih beragam sebagai pertimbangan dalam hal mengembangkan produk sejenis. Peneliti lain juga dapat melanjutkan penelitian ini pada tahap implementasi melalui penelitian eksperimen.

\section{Daftar Pustaka}

Abdullah, R. 2015. Urgensi Penilaian Hasil Belajar Berbasis Kelas Mata Pelajaran IPS di Madrasah Tsanawiyah. Latanida Journal. Volume 3, No. 2.

Agung, A. A. G. 2011. Prosedur Penelitian Suatu Pendeketan Praktek. Singaraja: Universitas Pendidikan Ganesha.

Agustini, K. S. A., Gading, I. K., \& Tristayani, L. A. 2016. Pengaruh Metode Pembelajaran Eksperimen Terhadap Keterampilan Proses Sains Pada Kelompok B Semester II TK Kartika VII-3. e-Journal Pendidikan Anak Usia Dini Universitas Pendidikan Ganesha. Volume 4, No. 2, hlm. 1-10.

Aji, B. S., \& Winarno, M. E. 2016. Pengembangan Instrumen Penilaian Pengetahuan Mata Pelajaran Pendidikan Jasmani Olahraga dan Kesehatan (PJOK) Kelas VIII Semester Gasal. Jurnal Pendidikan: Teori, Penelitian, dan Pengembangan. Volume 1, No. 7, hlm. 1449-1463.

Andriani, R., \& Rasto, R. 2019. Motivasi Belajar Sebagai Determinan Hasil Belajar Siswa. Jurnal Pendidikan Manajemen Perkantoran. Volume 4, No. 1, hlm. 80-86.

Arjuniwati, A. 2019. Meningkatkan Motivasi dan Hasil Belajar Melalui Penerapan Model Pembelajaran Numbered Heads Together (NHT) Pada Materi Peluang Mata Pelajaran Matematika Kelas XII. Jurnal Pendidikan Tambusai. Volume 3, No. 1, hlm. 1-13.

Astalini, \& Kurniawan, D. A. 2019. Pengembangan Instrumen Sikap Siswa Sekolah Menengah Pertama Terhadap Mata Pelajaran IPA. Jurnal Pendidikan Sains (JPS). Volume 7, No. 1, hlm. 1-7.

Candiasa, I. M. 2011. Pengujian Instrumen Penelitian Disertai Aplikasi ITEMAN dan BIGSTEPS. Singaraja: Universitas Pendidikan Ganesha.

Dewi, N. D. L., \& Prasetyo, Z. K. 2016. Pengembangan Instrumen Penilaian IPA Untuk Memetakan Critical Thinking dan Practical Skill Peserta Didik SMP. Jurnal Inovasi Pendidikan IPA. Volume 2, No. 2, hlm. 213-222.

Dewi, N. R., \& Akhlis, I. 2016. Pengembangan Perangkat Pembelajaran IPA Berbasis Pendidikan Multikultural Menggunakan Permainan Untuk Mengembangkan Karakter Siswa. Unnes Science Education Journal. Volume 5, No. 1, hlm. 1098-1108.

Hamid, M. A. 2016. Pengembangan Instrumen Penilaian Hasil Belajar Siswa Berbasis TIK Pada Pembelajaran Dasar Listrik Elektronika. Jurnal IImiah Pendidikan Teknik Elektro. Volume 1, No. 1, hlm. 37-46.

Hardiani, I. N. 2017. Pengembangan Pengembangan Instrumen Penilaian Sikap Sosial Pembelajaran IPS Kelas IV SD. Jurnal Mitra Pendidikan. Volume 1, No. 6, hlm. 25500481.

Hayati, S., \& Lailatussaadah. 2016. Validitas dan Reliabilitas Instrumen Pengetahuan Pembelajaran Aktif, Kreatif dan Menyenangkan (PAKEM) Menggunakan Model Rasch. 
Jurnal IImiah DIDAKTIKA. Volume 16, No. 2, hIm. 169-179.

Huntaruk, P., \& Simbolon, R. 2018. Meningkatkan Hasil Belajar Siswa Dengan Alat Peraga Pada Mata Pelajaran IPA Kelas IV SDN Nomor 14 Simbolon Purba. SEJ(School Education Journal). Volume 8, No. 2, hlm. 121-129.

Koyan, I. W. 2011. Assesment Dalam Pendidikan. Singaraja: Undiksha Press.

Marwah, S. S., Syafe'i, M., \& Sumarna, E. 2018. Relevansi Konsep Pendidikan Menurut Ki Hadjar Dewantara Dengan Pendidikan Islam. Indonesian Journal of Islamic Education. Volume 5, No. 1, hlm. 14-26.

Maulida, E. F. J., \& Mukminan. 2016. Implementasi Teams Games Tournaments Berbantuan Media Untuk Meningkatkan Hasil Belajar dan Sikap Terhadap Pembelajaran IPS. Harmoni Sosial: Jurnal Pendidikan IPS. Volume 3, No. 1, hlm. 27-38.

Muttaqin, M. Z., \& Kusaeri, K. 2017. Pengembangan Instrumen Penilaian Tes Tertulis Bentuk Uraian Untuk Pembelajaran Pai Berbasis Masalah Materi Fiqh. Jurnal Tatsqif. Volume 15, No. 1, hlm. 1-23.

Norazaini. 2017. Peningkatan Hasil Belajar IPA Menggunakan Media Lingkungan Alam Pada Siswa Kelas III. Jurnal Pendidikan Guru Sekolah Dasar. Volume 7, No. 6, hlm. 716-722.

Purnomo, P., \& Palupi, M. S. 2016. Pengembangan Tes Hasil Belajar Matematika Materi Menyelesaikan Masalah yang Berkaitan dengan Waktu, Jarak dan Kecepatan Untuk Siswa Kelas V. Jurnal Penelitian (Edisi Khusus PGSD). Volume 20, No. 2, hlm. 151-157.

Sugiyono. 2017. Metode Penelitian Kuantitatif, Kualitatif, dan R\&D. Bandung: Alfabeta.

Suharman. 2018. Tes Sebagai Alat Ukur Prestasi Akademik. Jurnal Ilmiah Pendidikan Agama Islam. Volume 10, No. 1, hlm. 93-115.

Sujana, I. W. C. 2019. Fungsi dan Tujuan Pendidikan Indonesia. ADI WIDYA: Jurnal Pendidikan Dasar. Volume 4, No. 1, hlm. 29-39.

Trimawati, K., Kirana, T., \& Raharjo, R. 2020. Pengembangan Instrumen Penilaian IPA Terpadu Dalam Pembelajaran Model Project Based Learning (PJBL) Untuk Meningkatkan Kemampuan Berpikir Kritis dan Kreatif Siswa SMP. QUANTUM: Jurnal Inovasi Pendidikan Sains. Volume 11, No. 1, hlm. 36-52.

Uno, H. B. 2008. Teori Motivasi \& Pengukuran. Jakarta: PT Bumi Aksara.

Yusuf, M. 2015. Asesmen dan Evaluasi Pendidikan: Pilar Penyedia Informasi dan Kegiatan Pengendali Mutu Pendidikan. Jakarta: Prenadamedia Group. 